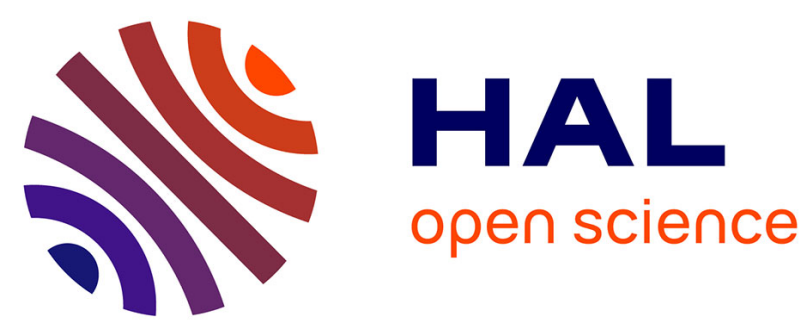

\title{
Evaluation and selection of indicators for land degradation and desertification monitoring: types of degradation, causes, and implications for management
}

C. Kosmas, Or. Kairis, Ch. Karavitis, C. Ritsema, L. Salvati, S. Acikalin, M. Alcalá, P. Alfama, J. Atlhopheng, J. Barrera, et al.

\section{To cite this version:}

C. Kosmas, Or. Kairis, Ch. Karavitis, C. Ritsema, L. Salvati, et al.. Evaluation and selection of indicators for land degradation and desertification monitoring: types of degradation, causes, and implications for management. Environmental Management, 2014, 54 (5), pp.971-982. 10.1007/s00267013-0109-6 . ird-01223238

\section{HAL Id: ird-01223238 \\ https://hal.ird.fr/ird-01223238}

Submitted on 2 Nov 2015

HAL is a multi-disciplinary open access archive for the deposit and dissemination of scientific research documents, whether they are published or not. The documents may come from teaching and research institutions in France or abroad, or from public or private research centers.
L'archive ouverte pluridisciplinaire HAL, est destinée au dépôt et à la diffusion de documents scientifiques de niveau recherche, publiés ou non, émanant des établissements d'enseignement et de recherche français ou étrangers, des laboratoires publics ou privés. 


\title{
Evaluation and Selection of Indicators for Land Degradation and Desertification Monitoring: Types of Degradation, Causes, and Implications for Management
}

\author{
Or. Kairis - C. Kosmas $\cdot$ Ch. Karavitis $\cdot$ C. Ritsema $\cdot$ L. Salvati $\cdot$ S. Acikalin $\cdot$ M. Alcalá $\cdot$ \\ P. Alfama - J. Atlhopheng - J. Barrera - A. Belgacem - A. Solé-Benet - J. Brito - M. Chaker • \\ R. Chanda $\cdot$ C. Coelho $\cdot$ M. Darkoh $\cdot$ I. Diamantis $\cdot$ O. Ermolaeva $\cdot$ V. Fassouli $\cdot$ W. Fei $\cdot$ \\ J. Feng $\cdot$ F. Fernandez $\cdot$ A. Ferreira $\cdot$ C. Gokceoglu $\cdot$ D. Gonzalez $\cdot$ H. Gungor $\cdot$ R. Hessel $\cdot$ \\ J. Juying $\cdot$ H. Khatteli $\cdot$ N. Khitrov $\cdot$ A. Kounalaki $\cdot$ A. Laouina $\cdot$ P. Lollino $\cdot$ M. Lopes $\cdot$ \\ L. Magole $\cdot$ L. Medina $\cdot$ M. Mendoza $\cdot$ P. Morais $\cdot$ K. Mulale $\cdot$ F. Ocakoglu $\cdot$ M. Ouessar $\cdot$ \\ C. Ovalle $\cdot$ C. Perez $\cdot$ J. Perkins $\cdot$ F. Pliakas $\cdot$ M. Polemio $\cdot$ A. Pozo $\cdot$ C. Prat $\cdot$ Y. Qinke $\cdot$ \\ A. Ramos $\cdot$ J. Ramos $\cdot$ J. Riquelme $\cdot$ V. Romanenkov $\cdot$ L. Rui $\cdot$ F. Santaloia $\cdot$ R. Sebego $\cdot$ \\ M. Sghaier $\cdot$ N. Silva $\cdot$ M. Sizemskaya $\cdot$ J. Soares $\cdot$ H. Sonmez $\cdot$ H. Taamallah $\cdot$ L. Tezcan $\cdot$ \\ D. Torri $\cdot$ F. Ungaro $\cdot$ S. Valente $\cdot$ J. de Vente $\cdot$ E. Zagal $\cdot$ A. Zeiliguer $\cdot$ W. Zhonging $\cdot$ A. Ziogas
}

Received: 9 July 2012/Accepted: 7 June 2013/Published online: 28 June 2013

(C) Springer Science+Business Media New York 2013

Abstract Indicator-based approaches are often used to monitor land degradation and desertification from the global to the very local scale. However, there is still little agreement on which indicators may best reflect both status and trends of these phenomena. In this study, various processes of land degradation and desertification have been analyzed in 17 study sites around the world using a wide

Or. Kairis · C. Kosmas (\&) · Ch. Karavitis · V. Fassouli ·

A. Kounalaki

Laboratory of Soils, Agricultural University of Athens,

Iera Odos 75, Athens 11855, Greece

e-mail: ckosm@aua.gr

C. Ritsema · R. Hessel

Alterra, Wageningen UR, Wageningen, The Netherlands

L. Salvati

Consiglio per la Ricerca e la sperimentazione in Agricoltura,

(CRA-RPS), Rome, Italy

S. Acikalin · C. Gokceoglu · H. Gungor - F. Ocakoglu •

H. Sonmez $\cdot$ L. Tezcan

Eskisehir Osmangazi University, Eskisehir, Turkey

M. Alcalá · D. Gonzalez · L. Medina · M. Mendoza ·

C. Prat $\cdot$ A. Ramos $\cdot$ J. Ramos

Institut de Recherche pour le Développement, Mexico, Mexico

P. Alfama $\cdot$ J. Brito $\cdot$ N. Silva

National Institute for Agriculture Research and Development,

Praia, Cape Verde set of biophysical and socioeconomic indicators. The database described earlier in this issue by Kosmas and others (Environ Manage, 2013) for defining desertification risk was further analyzed to define the most important indicators related to the following degradation processes: water erosion in various land uses, tillage erosion, soil salinization, water stress, forest fires, and overgrazing. A
J. Atlhopheng - R. Chanda - M. Darkoh · L. Magole

K. Mulale - J. Perkins $\cdot$ R. Sebego

University of Botswana, Gaborone, Botswana

J. Barrera · F. Fernandez - C. Ovalle - C. Perez - A. Pozo · J. Riquelme $\cdot$ E. Zagal

Instituto de Investigaciones Agropecuarias, Santiago, Chile

A. Belgacem - H. Khatteli - M. Ouessar - M. Sghaier .

H. Taamallah

Institut des Regions Arides, Medenine, Tunisia

A. Solé-Benet · J. de Vente

Estacion Experimental de Zonas Áridas (EEZA-CSIC),

Almeria, Spain

M. Chaker · A. Laouina

Chair UNESCO-GN, University of Mohamed V, Rabat, Morocco

C. Coelho $\cdot$ J. Soares $\cdot$ S. Valente

University of Aveiro, Aveiro, Portugal 
correlation analysis was applied to the selected indicators in order to identify the most important variables contributing to each land degradation process. The analysis indicates that the most important indicators are: (i) rain seasonality affecting water erosion, water stress, and forest fires, (ii) slope gradient affecting water erosion, tillage erosion and water stress, and (iii) water scarcity soil salinization, water stress, and forest fires. Implementation of existing regulations or policies concerned with resources development and environmental sustainability was identified as the most important indicator of land protection.

Keywords Indicators $\cdot$ Land degradation $\cdot$ Desertification . Meta-analysis

\section{Introduction}

Indicators are becoming increasingly important for communicating information to policy makers and the general public, as well as for assessing the environmental performance and the progress made by actions applied to mitigate land degradation and desertification (Rubio and Bochet 1998; Kosmas and others 1999; Basso and others 2000; Kosmas and others 2003; Salvati and others 2008). As it has been pointed out by the United Nations Convention to Combat Desertification (UNCCD), indicators may be considered as valuable tools for assessing desertification risk and for analyzing the effectiveness of the various land management practices for combating desertification (Rubio and Bochet 1998, COP 2009; Kosmas and others 2003; Brandt 2005; Sommer and others 2011; Ferrara and others 2012). By using an appropriate set of indicators, the status and trends of complex processes such as soil erosion, soil salinization, and desertification may be effectively described without using complex mathematical expressions or

I. Diamantis · F. Pliakas · A. Ziogas

Democritus University of Thrace, Komotini, Greece

O. Ermolaeva · N. Khitrov · V. Romanenkov ·

M. Sizemskaya $\cdot$ A. Zeiliguer

Moscow State University of Environmental Engineering,

Moscow, Russia

W. Fei $\cdot$ J. Feng $\cdot$ J. Juying $\cdot$ Y. Qinke $\cdot$ L. Rui $\cdot$ W. Zhonging Institute of Soil and Water Conservation, Yangling, China

A. Ferreira $\cdot$ M. Lopes $\cdot$ P. Morais

Escola Superior Agraria de Gois, Coimbra Portugal

P. Lollino - M. Polemio - F. Santaloia $\cdot$ D. Torri $\cdot$ F. Ungaro

Research Institute for Hydrogeological Protection, Perugia, Italy models that require an excessive amount of data (Kosmas and others 2003; Rubio and Recatala 2006; Salvati and Bajocco 2011).

An environmental indicator is a variable that describes the state of the environment and its impact on human beings, ecosystems, materials, the pressures on the environment, the driving forces, and the responses steering that system (Hammond and others 1995; Niemeijer and de Groot 2008; ETDS 2010). In environmental sciences, a single indicator cannot efficiently describe a complex process such as soil erosion or land desertification. However, indicators combined to create a composite index permit multiple assessments to be made in various systems and hence to monitor the state of the environment or compare different sub-systems (Rubio and Bochet 1998; Kosmas and others 2003; Salvati and Zitti 2009).

Many authors have considered that classification of desertification indicators should take into account linkages between: (i) the pressures exerted on the environment by human activities, (ii) the changes in the quality of environmental components, and (iii) the societal responses to these changes. This can make indicators a useful and valuable tool for land-users and policy makers (O' Connor 1994; Pieri and others 1995; SCOPE 1995; Dumanski and Pieri 1996; Brandt 2005; Niemeijer and de Groot 2008).

Recatala and others (2002) reported environmental indicators to assess and monitor desertification and its influence on environmental quality in Mediterranean ecosystems. As an example, stocking rate is an important global indicator according to Pulina and others (1998), which takes into account all factors influencing the impact of grazers on soil and on land degradation and desertification processes. Fierotti and Zanchi (1998) suggested degree of soil erosion as a global indicator, but this variable cannot be easily and rapidly assessed without field observations. The estimation of soil erosion, however, can be assisted by other specific indicators such as the development and intensity of erosive forms, the trend of various soil physical characteristics, organic matter content, vegetation growth rate, degree of vegetation cover, and its productivity (Fierotti and Zanchi 1998). The ENVASSO project (Kibblewhite and others 2007) selected three headline soil-linked desertification indicators related to three treats (soil erosion, organic matter decline, and soil salinization) as the most relevant indicators of land degradation and desertification in the arid, semi-arid, and dry-sub-humid zones. The objective of this study was to evaluate the effectiveness of using indicators for assessing processes of land degradation and desertification at the global scale and to select those indicators that proved most relevant for assessing the various land management practices to combat desertification in a wide range of physical, environmental, social, and economic conditions represented by 
the study sites illustrated earlier in this issue by Kosmas and others (2013).

\section{Methods}

To define effective indicators for the assessment of land degradation and desertification and of the effectiveness of various land management practices for combating them, data for the selected indicators were collected from a variety of land uses, climatic conditions, soil and topographic characteristics, social and economic characteristics. Such data were collected from 17 study sites located in various areas around the world sensitive to land degradation and desertification. More specifically, the data were collected from the following study sites located along Mediterranean Europe, eastern Europe, Africa, Asia, and Latin America: (1) Rendina basin Basilicata-Italy, (2) Nestos basin Maggana-Greece, (3) Crete island-Greece, (4) Mação area-Portugal, (5) Gois area-Portugal, (6) Guadalentin basin SE-Spain, (7) Konya Karapinar plain-Turkey, (8) Eskisehir plain-Turkey, (9) Novij Saratov-Russia, (10) Djanybek area-Russia, (11) Zeuss Koutine-Tunisia, (12) Boteti area-Botswana, (13) Santiago island-Cape Verde, (14) Mamora Sehoul-Morocco, (15) Loess Plateau-China, (16) Secano Interior-Chile, and (17) Cointzio catchmentMexico. Questionnaires were prepared separately for each land degradation process or cause, including a series of possible effective indicators (Kosmas and others 2013 in this issue). Data were collected at the scale of field sites, usually ranging from 0.5 to 20 ha, and having uniform soil, topographic, land use, and land management characteristics. To harmonize data collection among the study sites, a manual was compiled defining each indicator and describing the methodology or technique for measuring it (DESIRE 2010).

The data used to calculate desertification risk [fully described in Kosmas and others (2013) in this issue] were further analyzed to define the most important indicators related to the various processes of land degradation and desertification. For this purpose, a Spearman correlation analysis was performed in order to evaluate linear and nonlinear relationships between the indicators in each land degradation process.

Soil erosion was used as dependent variable for comparison of the study sites in which water erosion and tillage erosion were identified as important processes of land degradation. Soil erosion was described by assessing the degree of soil erosion during the field survey. It was characterized according to: (i) the presence or absence of the soil surface A-horizon, (ii) the existence and percentage of eroded spots, (iii) the degree of exposure of the parent material on the soil surface, and (iv) the presence of gullies
(Kaihura and others 1999; Kosmas and others 2000a). The following five classes of erosion were used: no erosion, slight, moderate, severe, and very severe erosion. The degree of soil erosion is widely used in soil surveys. .The indicators soil water storage capacity and soil electrical conductivity were used as dependent variable for the field sites in which water stress and soil salinization, respectively, were considered the dominant processes. The indicators Grazing intensity and Rate of burned area were compared with the other indicators for the field sites in which overgrazing and forest fires were identified the dominant causes of land degradation.

Starting from the list reported earlier in this issue (Kosmas and others 2013), between 16 and 49 different indicators were used for the analysis. Important indicators considered for the comparative analysis of the field sites were those with correlation coefficients values greater than 0.40 (significance level $\mathrm{a}=0.05$ ). This threshold has been selected after comparing the various correlation matrixes obtained from the analysis in which the number of indicators extracted from the whole list ranged between a minimum value of 6 to a maximum value of 14 .

\section{Results and Discussion}

\section{Processes and Causes of Land Degradation}

The main processes or causes of land degradation documented in the 17 DESIRE sites including 1672 sample points: (a) soil erosion including water (806 of the sample points) and tillage erosion (283), (b) soil salinization (258), (c) water stress (258), (d) forest fires (85), and (e) overgrazing (265: see Table 1). In 283 sample points, more than one process was identified as importantly affecting land degradation, the most frequent processes being: (a) water stress and overgrazing, (b) water stress and water erosion, (c) tillage erosion and water erosion.

\section{Soil Erosion}

Soil erosion was found to be an important land degradation and desertification process documented in the following 13 field sites: Rendina Basin Basilicata-Italy, Crete-Greece, Guadalentin Basin Murcia-Spain, Konya Karapinar-Turkey, Eskisehir Plain-Turkey, Novij Saratov-Russia, Zeuss Koutine-Tunisia, Boteti Area-Botswana, Santiago IslandCape Verde, Mamora Sehoul-Morocco, Loess PlateauChina, Secano Interior-Chile, and Cointzio catchmentMexico.

A moderate degree of soil erosion was most frequently observed at $33.6 \%$ of the sample points (Fig. 1). The majority of the points with moderate erosion are located in 
Table 1 Land degradation processes and causes with the

corresponding land-use and distribution in the study sites

\begin{tabular}{|c|c|c|c|c|c|}
\hline $\mathrm{a} / \mathrm{a}$ & $\begin{array}{l}\text { Degradati } \\
\text { on process }\end{array}$ & Prevalent land-use & $\begin{array}{l}\text { Number of } \\
\text { study sites }\end{array}$ & $\begin{array}{l}\text { Number of } \\
\text { field sites }\end{array}$ & $\begin{array}{l}\text { Number of } \\
\text { used indicators }\end{array}$ \\
\hline \multirow[t]{3}{*}{1} & \multirow{3}{*}{$\begin{array}{l}\text { Soil erosion by } \\
\text { water runoff }\end{array}$} & Agriculture & 9 & 477 & 49 \\
\hline & & Pasture & 8 & 244 & 49 \\
\hline & & Forest & 6 & 85 & 49 \\
\hline 2 & Tillage erosion & Agriculture & 4 & 283 & 16 \\
\hline 2 & Soil salinization & Agriculture, natural vegetation & 6 & 258 & 29 \\
\hline 3 & Water stress & Agriculture, natural vegetation & 4 & 258 & 50 \\
\hline 4 & Overgrazing & Natural vegetation, agriculture & 6 & 265 & 44 \\
\hline 5 & Forest fires & Natural vegetation & 4 & 85 & 30 \\
\hline
\end{tabular}

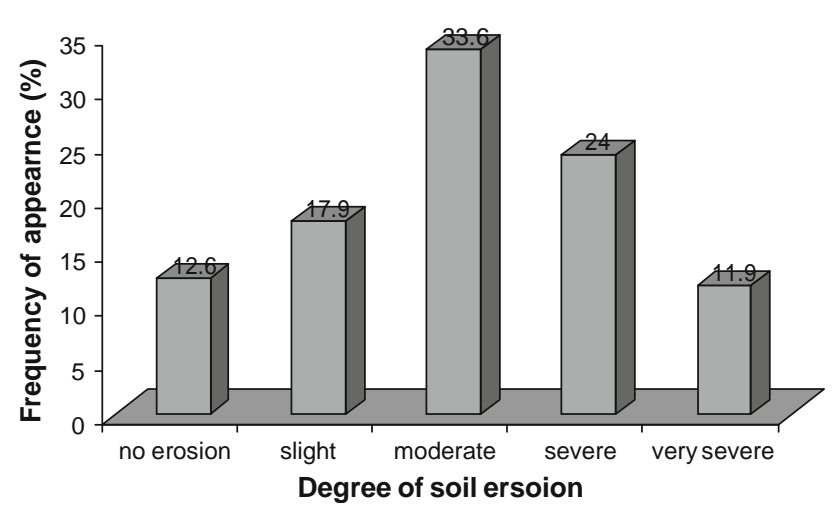

Fig. 1 Distribution of the degree of soil erosion classes in the study field sites

agricultural or forested areas characterized by moderate to steep slopes with moderate deep to shallow soils and inadequate (less than $50 \%$ ) plant cover. Severe $(24.0 \%$ of sampling points) and very severe erosion were associated with the presence of gullies found mainly in agricultural or grazing lands. No erosion $(12.6 \%)$ or slight erosion $(17.9 \%)$ was identified in the rest of sample points. Such levels of soil erosion have been mainly identified in field sites located in agricultural or forested areas with adequate plant cover (greater than $75 \%$ ), or properly managed and protected from degradation by applying soil erosion control measures. However, there are not soil erosion measurements in the study field sites but the whole approach of using indicators is to assess about erosion and land desertification risk in the absence of data of soil erosion. As a result, assigning classes to indicators is often a matter of expert opinion rather than measurement (although there can be exceptions).

The analysis of the indicators related to the degree of soil erosion including agriculture, pastures, and forest land uses showed that the most important indicators affecting soil erosion were related to the climate, vegetation, soil, agriculture, land management, husbandry, water use, landuse, social and institutional characteristics of the sample points (Fig. 2). The most important vegetation indicator was plant cover, negatively affecting soil erosion. Sample points with permanent plant cover higher than $50 \%$ were adequately protected from soil erosion.

The most important soil indicators affecting the degree of soil erosion were slope gradient, slope aspect, and the presence of Rock fragments in the soil surface. Moderate and severe soil erosion was usually identified on slopes steeper than $12 \%$. Sample points located in steep southfacing slopes were usually highly eroded compared to points with lower gradients on north-facing slopes (most of study sites are located in the northern hemisphere). The presence of high percentage of rock fragments in the soil surface $(15 \%)$ reduced surface water runoff and resulted in less soil erosion.

Annual Potential evapotranspiration and Rainfall seasonality were the most important climate indicators affecting the degree of erosion. Potential evapotranspiration was positively related to degree of soil erosion. Sample points located in areas with evapotranspiration rates greater than $1,200 \mathrm{~mm}$ per year had characterized with moderate or severe degree of soil erosion. Points located in areas of high Rainfall seasonality (0.60) were found to be subjected to higher soil erosion. High Seasonality means that a large fraction of annual precipitation falls in only a few months per year.

The most important runoff indicator affecting soil erosion was drainage density (including main rivers, and streams), which was found to be positively related to soil erosion. Moderate to severe erosion was found in points with high drainage density network. This indicator is interrelated with the type of parent material and land-use type affecting infiltration rates and therefore drainage density and soil erosion.

As expected, actions for soil erosion control had a great effect on the degree of erosion, the most important being runoff water storage. Sample points, in which actions for storing surface runoff are undertaken were usually subjected to slight or no erosion. Interestingly, terracing was positively related to the degree of soil erosion. Sample points with high percentage of Terracing had higher soil 

affecting soil erosion by surface water runoff in field sites located in agricultural, grazing, and forested areas
Fig. 2 Important indicators

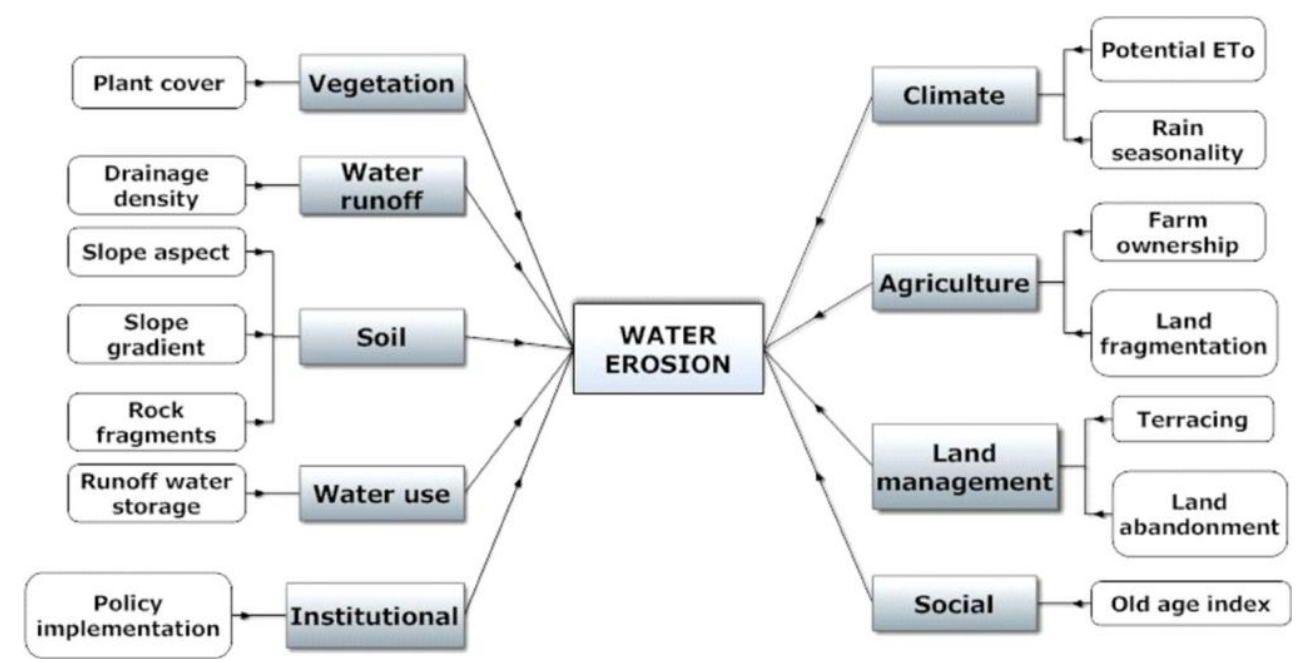

Fig. 3 Important indicators affecting tillage erosion in the study field sites

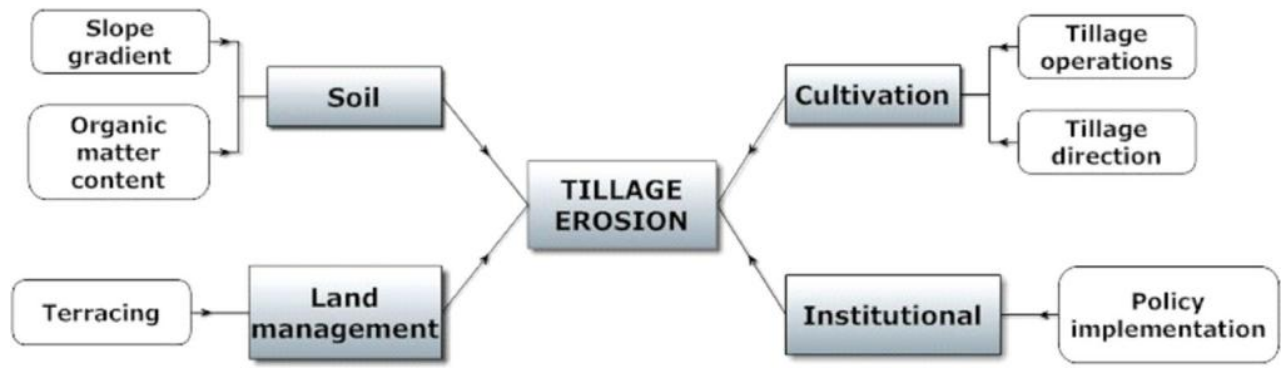

erosion rates, perhaps due to poor design or maintenance of terraces, or perhaps because terraces tend to be constructed in terrain sensitive to erosion where even higher rates occurred before terrace construction. Sample points located in areas with high rate of Land abandonment (higher than 25 ha per 10 years per $10 \mathrm{~km}^{2}$ ) were subjected to higher soil erosion. The correlation found for other actions such as sustainable farming, or soil erosion control measures was relatively low. Finally, in sample points where existing regulations for land protection were implemented, the degree of soil erosion was moderate to low.

The most important indicators related to agriculture and affecting soil erosion were Land fragmentation and Farm ownership. Sample points on farms with high land fragmentation (higher than ten parcels per farmer) were subjected to moderate or severe soil erosion. Furthermore, points located in areas with high elderly index (higher than $10 \%$ ) were subjected to moderate or severe erosion due to unwillingness or inability of old-aged farmers to apply measures for soil erosion protection.

\section{Tillage Erosion}

Another important process of land degradation was tillage erosion, which was evaluated in the following four study sites: Rendina basin Basilicata-Italy, Boteti area-Botswana,
Loess Plateau-China, and Crete island-Greece. Tillage erosion is attributed to the soil displacement caused by the tillage implements. As Fig. 3 shows, important indicators affecting this type of erosion were related to soil, cultivation, land management, and institutional characteristics. As was proven in previous research (Govers and others 1994; Lobb 1995; Tsara and others 2001), Slope gradient is one of the most important parameters affecting tillage erosion rates. This study also showed that tillage erosion was positively related to slope gradient. Sample points located in agricultural areas with slopes greater than $12 \%$ were subjected to moderate or severe erosion. Furthermore, points with low organic matter content $(\mathbf{2} \%)$ in the surface horizon showed moderate or severe erosion.

Among indicators related to cultivation, Tillage operations and Tillage direction significantly affected soil erosion. Sample points subjected to ploughing, disking or harrowing showed moderate or severe erosion as were points where cultivation was conducted in the down slope or oblique direction. In contrast, land Terracing was negatively related to tillage erosion. Points with high percentage of terraces (greater than 50\%) were subjected to a slight degree of tillage erosion since in such cases land is usually not cultivated or cultivation is carried out along the contour lines. Finally, in agricultural areas where some measures of soil protection were applied, soil erosion was significantly reduced. 
Fig. 4 Important indicators related to soil salinization in the study field sites

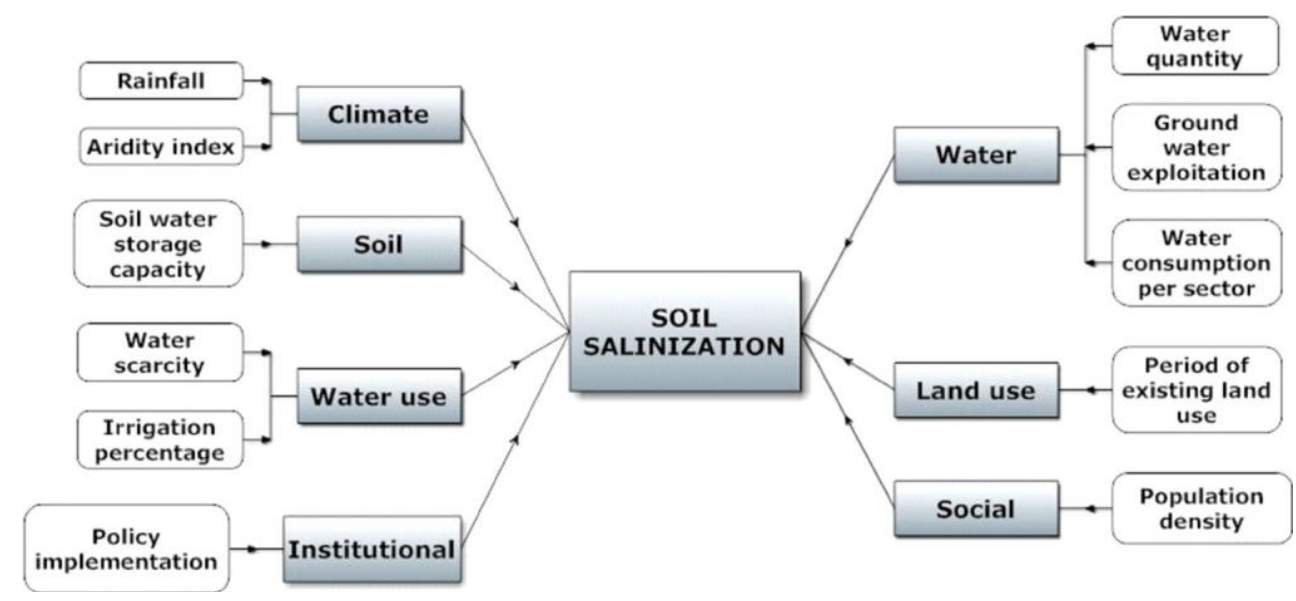

\section{Soil Salinization}

Soil salinization was an important land degradation process documented in the following six field sites: Nestos basin Maggana-Greece, Boteti area-Botswana, Konya Karapinar plain-Turkey, Novij Saratov-Russia, Djanybek-Russia, and Crete island-Greece. The most important indicators affecting soil salinization are related to climate, soil, water, water use, land-use, social and institutional characteristics (Fig. 4). Aridity index and Annual rainfall are the most important climate indicators. Areas characterized by high aridity indices (Bagnouls-Gaussen aridity index [125) combined with low amounts of rainfall $(1650 \mathrm{~mm})$ are more likely to be affected by soil salinization.

Indicators related to water resources or water use have a great impact on soil salinization. Among the most important indicators identified in the sample points were water quantity, ground water exploitation, water consumption/ water demands, irrigation percentage of arable land, and water scarcity (Fig. 4). Areas of low water availability accompanied by over-exploitation of ground and surface water resources were more vulnerable to secondary soil salinization. Furthermore, under high rates of water consumption/water demands (WC/WD [ 1), soil salinization was more likely to occur. In addition, when good quality water was available for expansion of irrigation of the land, soil salinization risk was reduced. Areas characterized by high water scarcity (water available supply per capita / water consumption per capita during the last 10 years [0.5) were more vulnerable to soil salinization.

The most important soil indicator affecting soil salinization was soil water storage capacity. Soils of high water storage capacity resulted, on average, as more vulnerable to soil salinization. Soil water storage capacity is affected by various soil properties such as soil texture, porosity, etc., therefore moderately fine and fine-textured soils were more likely to be affected by salinization. The period of existing land-use was a key indicator related to soil salinization.
Areas with a period of existing land use greater than 30 years were more likely to be affected by soil salinization. This can be attributed to factors such as climate change, expansion of irrigation, over-exploitation of water resources, and low policy implementations of existing regulations on natural resources protection. In addition, salt slowly accumulated while soil is used for agriculture.

Population density has been defined as another crucial indicator related to soil salinization in the study sites. High population density (100 people per $\mathrm{km}^{2}$ ) leads to overexploitation of water resources, chemical degradation of water quality, and soil salinization in the irrigated land, but of course only in combination with certain climate and land-use (irrigation) conditions. Finally, if existing policies on environmental protection were implemented, then salinization risk was greatly reduced.

\section{Water Stress}

Water stress was identified and documented as important process in the following four study sites: Boteti areaBotswana, Konya Karapinar plain-Turkey, Novij SaratovRussia, and Crete island-Greece. Initially, 50 indicators were described at each of the sample points subjected to water stress but after statistical analysis this was reduced to just twelve significant indicators. The defined indicators are related to climate, soil, water and water use, vegetation, land-use, fires, water runoff, land management, tourism, social and institutional characteristics (Fig. 5). Water stress was found to be high in sample points subjected to high rainfall seasonality. Such conditions are usually found in areas with arid or semi-arid climatic conditions.

Water stress was also found to be high in areas of expanding rates of ground water exploitation and high water scarcity. In contrast, points located in areas characterized by high rate of impervious surface area expansion ([25 ha/10 km $\mathrm{km}^{2}$ of territorial/10 years) were subjected to lower water stress. 
Fig. 5 Important indicators affecting water stress in the study field sites

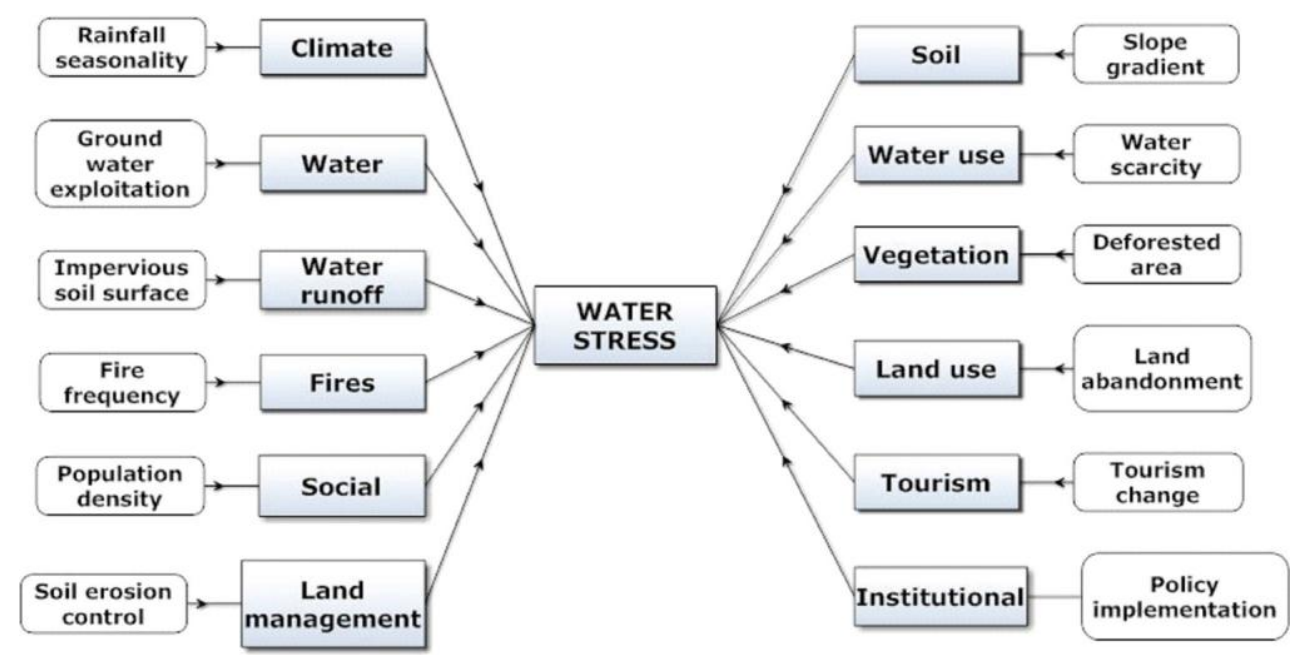

Fig. 6 Important indicators related to forest fires in field sites with dominant cause of land degradation and desertification

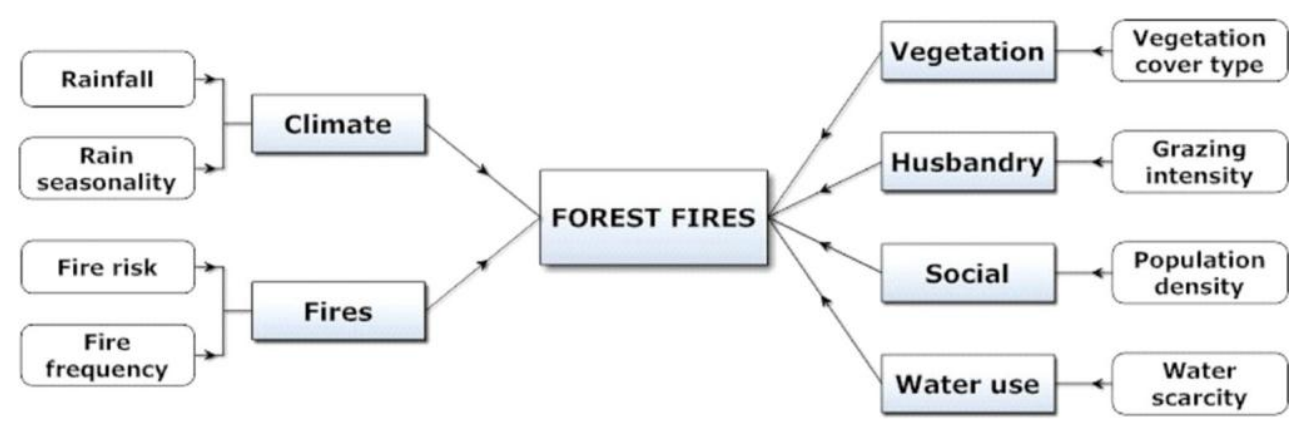

Under high slope gradients $(25 \%)$, the growing vegetation was subjected to higher water stress since surface water runoff was expected to be higher. The indicators rate of deforested area, rate of land abandonment, and fire frequency are negatively related to water stress. Under high rates of land abandonment or high fire frequency the growing plants are mainly removed reducing water demands and water stress risk. Water stress was negatively related to soil erosion control measures. High water stress was found for field sites in which no or low soil erosion control measures were undertaken.

Tourism change was positively related to water stress. Areas under high tourism change $15 \%$ number of overnight stays in a specific destination in 1 year averaged by overnight stays in the last 10 years) were more vulnerable since urban water consumption increases at the expense of water used for plant growth. The same trends with tourism change were found for the indicator population density. Finally, policy implementation contributed to mitigate water stress and thus desertification risk.

\section{Forest Fires}

The indicator for forest fires is defined as the average burned area per decade on a given territorial surface. Forest fires were identified as the main cause of land degradation and desertification in the following four study sites of: Mação area-Portugal, Cointzio catchment-Mexico, Gois area-Portugal and in few cases in the Boteti area-Botswana study sites. Analysis of the sample point data shows that forest fires were mainly related to climate, vegetation and associated characteristics, husbandry, water use, and social characteristics (Fig. 6). Indicators related to climate such as Annual rainfall, and Rainfall seasonality greatly affected the rate of burned area in the study sites. As rainfall decreased rate of burned area increased. Low amounts of rainfall combined with high rainfall seasonality favored extensive fires.

Important indicators related to vegetation characteristics were vegetation cover type and fire risk. Rate of burned area was found to be high in areas where the vegetation cover type was mixed Mediterranean macchia or matorral, pine forest, permanent and annual grass. Areas covered with high fire risk vegetation were subjected to high fire frequency (once every 25 years or less) and therefore the rate of burned was high, enhancing land degradation and desertification.

Over the last 50 years there has been a socio-economic transformation in the study sites from rural to urban areas. As a consequence there has been a reduction of grazing intensity resulting in a dramatic increase in the availability of vegetation fuel. This study's data have shown that rate 
of burned area has increased as grazing intensity and population density decreased.

An important indicator related to water use and affecting rate of burned area was water scarcity. Sample points located in areas with high water scarcity were subjected to low rates of burned area. Probably people living in such areas were more aware of the importance of protecting the environment by fighting against forest fires which greatly affected water availability. It may also be that biomass in the most water stressed environments is strongly reduced and therefore fire risk is also lower.

\section{Overgrazing}

Overgrazing is the result of pressure imposed on the growing vegetation by high intensity grazing. For sample points in which the main cause of land degradation was overgrazing, the main process was soil erosion due to surface water runoff. Overgrazing was identified and documented as important process of land desertification in the following three study sites: Boteti area-Botswana, Konya Karapinar plain-Turkey, and Djanybek-Russia.

As Fig. 7 shows, overgrazing was related to climate, soil, vegetation, agriculture, land-use, land management, water use, social and institutional characteristics. Annual potential evapotranspiration was the most important indicator related to climate that affected overgrazing. The rate of grazing intensity has been mainly defined as moderate to high in field sites located in areas characterized with high evapotranspiration rates.

Among the soil indicators, soil drainage, exposure of rock outcrops and organic matter surface horizon were especially affecting overgrazing. Overgrazing was found in areas with high percentage of rock outcrops. In such areas which were usually degraded, animals were seeking for food in a limited surface area consequently overgrazing it. Furthermore, poorly drained soils were covered mainly with palatable plant species all removed by the grazing animals. Finally, as was expected soil organic matter content was higher in field sites in which overgrazing was reduced.

Important indicators related to vegetation characteristics were vegetation cover type and rate of deforested area. Grazing intensity was found to be high in areas where the vegetation cover type was annual grasses and deciduous vegetation and where the rate of deforestation was relatively high (higher than $2.5 \%$ per year). In addition, grazing intensity and overgrazing was high in areas where the period of existing land use was high (30 years).

Among the indicators related to agriculture, farm ownership, and land fragmentation were significantly related to overgrazing. Tenant or state-farmed field sites were usually subjected to higher grazing intensity than owner or sharedfarmed field sites. Farmers used to use fire in grazing land to simulate the growth of palatable biomass production for the grazing animals thereby aggravating the problem of desertification in these areas. Furthermore, grazing land characterized by high fragmentation [10 parcels per farmer) was subjected to higher grazing intensity.

The only important land management indicator was soil water conservation measures such as mulching, temporary storage of water runoff. Field sites with few or no soil water conservation measures were usually subjected to overgrazing. In addition, areas characterized with high population growth rate (greater than $0.4 \%$ per year) were mainly subjected to overgrazing. Of course, in areas where policies on environmental protection were implemented, grazing land was subjected to lower grazing intensity.
Fig. 7 Important indicators related to overgrazing in field sites with the dominant cause of land degradation and desertification

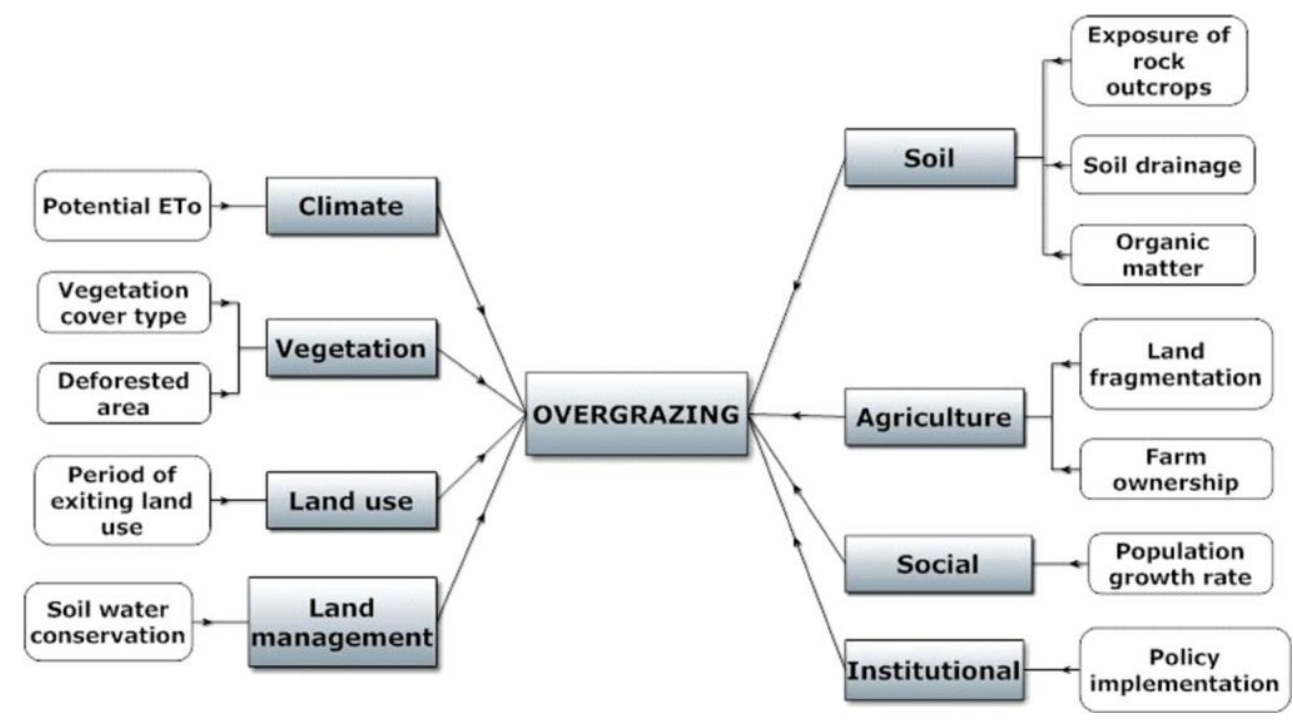


Table 2 Important indicators related to land protection in the various processes or causes of land degradation and desertification

\begin{tabular}{|c|c|c|c|c|c|c|}
\hline \multirow[t]{2}{*}{ Important indicators } & \multicolumn{6}{|c|}{ Processes important for desertification in study sites } \\
\hline & $\begin{array}{l}\text { Water } \\
\text { erosion }\end{array}$ & $\begin{array}{l}\text { Tillage } \\
\text { erosion }\end{array}$ & $\begin{array}{l}\text { Soil } \\
\text { salinization }\end{array}$ & $\begin{array}{l}\text { Water } \\
\text { stress }\end{array}$ & $\begin{array}{l}\text { Forest } \\
\text { fires }\end{array}$ & $\begin{array}{l}\text { Over- } \\
\text { grazing }\end{array}$ \\
\hline Runoff water storage & $\mathbf{h}$ & & & & & \\
\hline Land terracing & $\mathbf{h}$ & $\mathbf{h}$ & & & & \\
\hline Land abandonment & $\mathbf{h}$ & & & $\mathbf{h}$ & & \\
\hline Tillage operations & & $\mathbf{h}$ & & & & \\
\hline Tillage direction & & $\mathbf{h}$ & & & & \\
\hline Soil water conservation & & & & & & $\mathbf{h}$ \\
\hline Soil erosion control & & & & $\mathbf{h}$ & & \\
\hline Rate of deforested area & & & & $\mathbf{h}$ & & $\mathbf{h}$ \\
\hline Grazing intensity & & & & & h & \\
\hline Fire frequency & & & & $\mathbf{h}$ & & \\
\hline Irrigation percentage of arable land & & & $\mathbf{h}$ & & & \\
\hline Ground water exploitation & & & $\mathbf{h}$ & $\mathbf{h}$ & & \\
\hline Water consumption/water demands & & & $\mathbf{h}$ & & & \\
\hline Policy implementation & $\mathbf{h}$ & $\mathbf{h}$ & $\mathbf{h}$ & $\mathbf{h}$ & & $\mathbf{h}$ \\
\hline
\end{tabular}

Identifying Effective Indicators

As discussed above, the various processes or causes of land degradation are affected by a number of indicators related to physical environment and socioeconomic characteristics of the study sites. Indicators related to the physical environment cannot be easily altered. However, there are indicators which can be affected by human actions such as those related to cultivation, land-use, husbandry, land management, and water use. Table 2 summarizes the most important indicators identified in the study field sites for the various processes or causes which can be taken into consideration at field level to assess land degradation and desertification.

The most effective indicator controlling soil erosion identified in the study sites was runoff water storage. In contrast, land terracing and land abandonment favored higher soil erosion rates. Several studies have reported positive and negative effects on soil erosion due to land abandonment depending on the stage of land degradation at the time of abandonment (Kosmas 1995; Kosmas and others 2000; Grove and Rackham 2001). Similar results have been reported on soil erosion and land terracing in Mediterranean hilly areas (Martínez-Casasnovas and Sánchez-Bosch 2000; Ramos and Martinez-Casasnovas 2006).

Tillage erosion was greatly affected by Tillage operations and Tillage direction. Sloping areas frequently tilled downslope were highly eroded. Similar results have been reported in other studies (Govers and others 1999; Van Muysen and Govers 2002). Furthermore, tillage erosion was significantly reduced in sloping terraced areas since they were subjected to low land-use intensity.
Land management indicators that affected soil salinization in the study sites were irrigation percentage of arable land, ground water exploitation, and water consumption/ water demands. Areas subjected to over-exploitation of ground water resources and high water consumption/water demands ratios were more vulnerable to secondary soil salinization. In contrast, when water of good quality was available for the arable land irrigation expansion, soil salinization risk was reduced. Similar indicators and trends have been reported in other studies (MEDRAP 2004; DESERTLINKS 2004; Iannetta and Colonna 2009).

Land management indicators identified in areas subjected to water stress were the rate of deforested area, ground water exploitation, land abandonment, and soil erosion control. Water stress was reinforced in areas of high rates of ground water exploitation but alleviated under high rates of deforestation and land abandonment or high fire frequency. Soil erosion control was the most effective measure for reducing water stress. Interestingly, such indicators related to water stress have not been documented in other studies.

The most important indicator identified in areas affected by forest fires was grazing intensity. Under-grazing or nongrazing forested land resulted in dramatic increase in flammable dry biomass during summer period favoring extensive forest fires. Similar trends have been reported in other studies on the effect of grazing intensity and frequency of forest fires (Baeza and others 2007; Papanastasis 2009). Overgrazing land management indicators identified in the filed sites were deforested area and soil water conservation measures. Overgrazing is combined with high rates of deforestation and the absence of soil water 
conservation measures. Similar indicators related to overgrazing have been reported by FAO (1999). Finally, the implementation of existing regulations or policies on resources development and environmental sustainability (policy implementation) was found as the most important effective indicator affecting land protection due to various processes or causes of land degradation identified in the study field sites.

The results described in this paper show how the method developed by Kosmas and others (2013) and described earlier in this issue can be applied to identify the most important indicators for the different degradation processes. They show that a relatively small set of variables can be used with confidence to quickly assess desertification risk for different degradation processes in different contexts around the world. Of these effective indicators only some can be influenced by man. This information is highly relevant for defining land management options. In order to facilitate the application of the developed indices, a web-based expert system was developed by Karavitis and others (2013, this issue). Using this system it is possible to evaluate how much desertification risk would change by adapting management.

\section{Lessons Learned on Using Indicators}

The analysis of the existing data collected from the various study sites has shown that indicators may be widely, even globally, used for assessing land degradation processes or causes at the field (or local) level. Of course, some indicators related to agriculture, social, and institutional characteristics in some cases show trends that are opposite to what happens in other study sites. These trends can be explained by further investigation including other indicators or processes affecting land degradation and desertification that it was not possible to consider in this effort. Applied to land degradation and desertification, efficiency and performance indicators seem the most promising for further research, particularly combined with economic principles. In this regard policymaking may benefit using the indicators as an aid, a means to achieve more focus responses timely and accurately. However, the great number of indicators may be treated cautiously, since confusion or "noise" may proliferate leading to the same pre-existing obscurity for the selected policy responses.

Some indicators such as rain erosivity, parent material, soil depth, soil water storage capacity, rate of deforested area, parallel employment, sustainable farming, irrigation percentage of arable land, major land use, water consumption/water demands, Rock fragments, Slope aspect, Organic matter on the soil surface, farm size, tillage depth, tourism intensity, soil drainage, water quantity, ground water exploitation, Exposure of rock outcrops, Fire risk, and tourism change appeared in the analysis less frequently but are very important for some processes or causes of desertification such as soil salinization, water stress, overgrazing, and forest fires. There were also indicators such as mechanization index, reclamation of affected areas, reclamation of mining areas, percentage of urban area, rate of change of urban area, water consumption per sector, and population distribution that were not included in any process or cause of land degradation and desertification.

The standardized methodology (manual on indicators) for describing indicators used in this study did not work appropriately in some field sites for the following indicators: farm ownership (Boteti Area-Botswana, Mação-Portugal), vegetation cover type (Mação-Portugal, Boteti Area-Botswana, Novij Saratov-Russia), land fragmentation (Mamora Sehoul-Morocco), parallel employment (Mamora Sehoul-Morocco), tillage operations (Mamora SehoulMorocco, Santiago Island-Cape Verde), Major land use (Konya plain-Turkey, Boteti Area-Botswana, MaçãoPortrugal), land-use type (Boteti Area-Botswana), and grazing intensity (Mação-Portugal). The indicator system used in DESIRE project can be easily improved by including new classes for describing these indicators.

Some indicators such as policy implementation, population growth rate, old-age index were described as subjected to cause-effect relationships. In some cases cause and effect are reserved, and that in other cases there might be a correlation, but not a cause-effect relationship at all. This is particularly the case for indicators related to Policy implementation. Policy formulation on environmental protection is related to the politicians and can be related to the living conditions of the people or to the land management characteristics resulting in unfavourable changes in the physical environment.

However, some assumptions that are inherent in the use of indicators can be pointed out from this study. For example indicators basically give information on what happened in the past may also used to determine the risk of land degradation and desertification in the future if biophysical and socio-economic conditions remain the same. The use of expert opinion instead of measurements for some indicators can affect the accuracy and efficacy of assessing land degradation and desertification risk. However, by using indicators someone can predict very quickly the direction and the intensity qualitatively of a process or cause of land degradation in the absence of data or knowledge of processes.

\section{Conclusions}

The analyses show that indicators may be widely used for assessing the various land degradation and desertification 
processes or causes at field level. The indicators proposed in the present paper include both biophysical indicators describing, e.g., climate, soil, vegetation, and socio-economic indicators such as population density, tourism, forest fires, overgrazing which can be affected by complex processes such as deforestation, land abandonment or land terracing, all of which vary with time. In order to assess the level of land vulnerability to degradation due to various processes and causes, it is necessary to accurately define its present state and, if possible, its past states. Furthermore, land is subjected to a number of impacts affecting processes that either improve or degrade it. The rate of change depends on the intensity of impact factors, as well as, on the state of land at the observation time. Therefore, the vulnerability of land to degradation or improvement is not a constant state but changes rapidly over time and requires a continuous monitoring. When crucial factors such as soil depth, water scarcity, unsustainable human activity (such as continuing tilling of soil), or high grazing intensity reach or surpass critical thresholds, land is heading toward desertification. In some restricted cases, however, anthropogenic factors may reverse the course of land degradation, for example through improved management, and the proposed framework is capable to identify also territorial contexts characterized by the over mentioned conditions.

In assessing land degradation and desertification, efficiency and performance indicators seem the most promising for further research, particularly combined with economic principles. In this regard policymaking may benefit from the selected indicators as a tool to achieve more focused responses.

Acknowledgments The research described in this paper was conducted within the framework of the EC-DG RTD, 6th Framework Research Programme (sub-priority 1.1.6.3), Research on Desertification, project DESIRE (037046): Desertification Mitigation and Remediation of Land - a global approach for local solutions. The financial support by the European Commission was gratefully acknowledged.

\section{References}

Baeza MJ, Valdecantos A, Alloza JA, Vallejo VR (2007) Human disturbance and environmental factors as drivers of long-term post-fire regeneration patterns in Mediterranean forests. J Veg Sci 18:243-252

Basso F, Bove E, Dumontet S, Ferrara A, Pisante M, Quaranta G, Taberner M (2000) Evaluating environmental sensitivity at the basin scale through the use of geographic information systems and remotely sensed data: an example covering the Agri basinSouthern Italy. Catena 40:19-35

Brandt J (2005) Desertification information system to support National Action Programmes in the Mediterranean (DISMED). DIS4ME, Desertification Indicator System for Mediterranean Europe. www.unibas.it/desertnet/dis4me/using_dis4me/dismed.htm

COP (2009) Conference of the Parties. Advice on how best to measure progress on strategic objectives 1, 2 and 3 of the Strategy. Decision
17/COP.9. http://www.unccd.int/en/programmes/Science/Monitor ing-Assessment/Documents/Decision17COP9

DESERTLINKS (2004) Desertification Indicator System for Mediterranean Europe (DIS4ME). European Commission, Contract EVK2CT-2001-00109.http://www.kcl.ac.uk/projects/desertlinks/

DESIRE (2010) Desertification Mitigation and Remediation of land-a global approach for local solutions. Contract Number: 037046. EC-DG RTD - 6th framework research programme. http:// www.desire-his.eu/

Dumanski J, Pieri C (1996) Application of the pressure-state-response framework for the land quality indicators (LQI) programme. Proceedings of the workshop organized by the FAO Agriculture and Sustainable Development Departments, 25-26 January. FAO, Rome

ETDS-Environmental Terminology and Discovery Service: Information-Base (2010) European Environment Agency. http:// glossary.eea.europa.eu/EEAGlossary/E/environmental_indicator FAO:

Food and Agriculture Organization of the United Nations (1999)

Livestock and environment toolbox. http://www.fao.org/ ag/againfo/programmes/en/lead/toolbox/Refer/Indicat.htm

Ferrara A, Salvati L, Sateriano A, Nole A (2012) Performance evaluation and cost assessment of a key indicator system to monitor desertification vulnerability. Ecol Indic 23:123-129

Fierotti G, Zanchi C (1998) Agricultural practices and soil fertility degradation. In: $\mathrm{G}$ Enne, MD'Angelo and C Zanolla (eds) Indicators for assessing desertification in the Mediterranean. Proceedings of the International Seminar held in Porto Torres, Italy, 18-20 Sept 1998

Govers G, Vandaele K, Desmet PJJ, Poesen J, Bunte K (1994) The role of tillage in soil redistribution on hill slopes. Eur J Soil Sci 45:469-478

Govers G, Lobb DA, Quine TA (1999) Tillage erosion and translocation emergence of a new paradigm in soil erosion research. Soil Tillage Res 51:167-174

Grove AO, Rackham O (2001) The nature of Mediterranean Europe, an ecological history. Yale University Press, New Haven

Hammond A, Adriaanse A, Rodenburg E, Bryant D, Woodward R (1995) Environmental indicators: a systematic approach to measuring and reporting on environmental policy performance in the context of sustainable development. World Resources Institute, Washington, DC, p 50

Iannetta M, Colonna N (2009) Salinisation in the Mediterranean context. Booklet in the framework of the VI Framework Programma Priorità 1.1.6.3 Global Change and Ecosystems, EU SSA Lucinda Project

Kaihura FBS, Kullaya IK, Kilasara M, Aune JB, Singh BR, Lal R (1999) Soil quality effects of accelerated erosion and management systems in three eco-regions of Tanzania. Soil Tillage Res 53:59-70

Kibblewhite J, Rubio JL, Kosmas C, Jones R, Arrouays D, Huber S, Verheijen F (2007) Environmental assessment of soil for monitoring desertification in Europe. United Nations Convention for Combating Desertification, Madrid, p 62, 3-14 Sept 2007

Kosmas C (1995) Field site: Spata, Greece. MEDALUS II-Project 1, Basic Field Program, Final Report Covering the Period "1 January 1991 to 1 September 1995"

Kosmas C, Kirkby M, Geeson N (1999) Manual on: Key indicators of desertification and mapping environmentally sensitive areas to desertification. Eur Comm Energy Environ Sustain Dev EUR 18882:87

Kosmas C, St Gerontidis, Marathianou M (2000a) The effect of land use change on soil and vegetation over various lithological formations on Lesvos (Greece). Catena 40:51-68

Kosmas C, Danalatos NG, Gerontidis S (2000b) The effect of land parameters on vegetation performance and degree of erosion under Mediterranean conditions. Catena 40:3-17 
Kosmas C, Tsara M, Moustakas N, Karavitis C (2003) Land desertification and identification indicators. Ann Arid Zones 42:393-416

Kosmas C, Kairis O, Karavitis C, Ritsema C, Salvati L, Acikalin S, Alcalá M, Alfama P, Atlhopheng J, Barrera J, Belgacem A, SoléBenet A, Brito J, Chaker M, Chanda R, Coelho C, Darkoh M, Diamantis I, Ermolaeva O, Fassouli V, Fei W, Feng J, Fernandez F, Ferreira A, Gokceoglu C, Gonzalez D, Gungor H, Hessel R, Juying J, Khatteli H, Khitrov N, Kounalaki A, Laouina A, Lollino P, Lopes M, Magole L, Medina L, Mendoza M, Morais P, Mulale K, Ocakoglu F, Ouessar M, Ovalle C, Perez C, Perkins J, Pliakas F, Polemio M, Pozo A, Prat C, Qinke Y, Ramos A, Ramos J, Riquelme J, Romanenkov V, Rui L, Santaloia F, Sebego R, Sghaier M, Silva N, Sizemskaya M, Soares J, Sonmez $\mathrm{H}$, Taamallah H, Tezcan L, Torri D, Ungaro F, Valente S, de Vente J, Zagal E, Zeiliguer A, Zhonging W, Ziogas A (2013) Evaluation and selection of indicators for land degradation and desertification monitoring: methodological approach. Environ Manage. doi:10.1007/s00267-013-0109-6

Lobb DA, Kachanoski RG, Miller MH (1995) Tillage translocation and tillage erosion on shoulder slope landscape positions measured using ${ }^{137} \mathrm{Cs}$ as a tracer. Can J Soil Sci 75:211-218

Martínez-Casasnovas JA, Sánchez-Bosch I (2000) Impact assessment of changes in land use/conservation practices on soil erosion in the Penedès-Anoia vineyard region (NE Spain). Soil Tillage Res 57:101-106

MEDRAP (2004) The MEDRAP Concerted Action to support the Northern Mediterranean Action Programme to Combat Desertification. Workshops results and proceedings. In: Giuseppe Enne, Denis Peter, Chiara Zanolla, Claudio Zucca (eds) Centro Interdipartimentale di Ateneo Nucleo Ricerca Desertificazione Universita degli Studi di Sassari, Sassari, p 938

Niemeijer D, de Groot RS (2008) A conceptual framework for selecting environmental indicators sets. Ecol Indic 8:14-25

O' Connor JC (1994) Environmental performance monitoring indicators. In: Monitoring progress on sustainable development, a user-oriented workshop. World Bank, Washington, DC

Papanastasis V (2009) Mediterranean desertification landscapes: Grazing lands and pastoral landscapes. Booklet in the framework of the VI Framework Programma Priorità 1.1.6.3 Global Change and Ecosystems, EU SSA Lucinda Project

Pieri C, Dumanski J, Hamblin A, Young A (1995) Land quality indicators. World Bank, Washington, DC

Pulina G, D’Angelo M, Madrau S, Zucca C, Enne G (1998) Indicators of land use intensity in agropastoral ecosystems. In: G Enne, MD
Angelo and C Zanolla (eds), Indicators for assessing desertification in the Mediterranean. Proceedings of the International Seminar held in Porto Torres, Italy, 18-20 Sept 1998

Ramos MC, Martinez-Casasnovas JA (2006) Nutrient losses by runoff in vineyards of the Mediterranean Alt Penedès region (NE Spain). Agric Ecosyst Environ 113:356-363

Recatala L, Fabbri AG, Zink JA, Frances A, Sanchez I (2002) Environmental indicators for assessing and monitoring desertifciation and its influence on environmental quality in Mediterranean environments. In: Rubio J, Morgan RPC, Asins S, Andreu $\mathrm{V}$ (eds) Man and soil at the third millennium, vol 1, ESSC, Logrono, pp 897-910

Rubio JL, Bochet E (1998) Desertification indicators as diagnosis criteria for desertification risk assessment in Europe. J Arid Environ 39:113-120

Rubio JL, Recatala L (2006) The relevance and consequences of Mediterranean desertification including security aspects. In: Kepner WG, Rubio JL, Mouat DA, Pedrazzini F (eds) Desertification in the mediterranean region: a security issue. Springer, Valencia, pp 133-165

Salvati L, Bajocco S (2011) Land sensitivity to desertification across Italy: past, present, and future. Appl Geogr 31:223-231

Salvati L, Zitti M (2009) Assessing the impact of ecological and economic factors on land degradation vulnerability through multiway analysis. Ecol Indic 9:357-363

Salvati L, Zitti M, Ceccarelli T (2008) Integrating economic and ecological indicators in the assessment of desertification risk: suggestions from a case study. Appl Environ Ecol Res 6:129138

SCOPE (1995) Environmental indicators: a systematic approach to measuring and reporting on the environment in the context of sustainable development. In: Gouzee N, Mazija B, Bharz SB (eds) Indicators of sustainable development for decision-making. Federal Planning Office, Brussels

Sommer S, Zucca C, Grainger A, Cherlet M, Zougmore R, Sokona Y, Hill J (2011) Application of indicator systems for monitoring and assessment of desertification from national to global scales. Land Degrad Dev 22(2): 184-197

Tsara M, Gerontidis S, Marathianou M, Kosmas C (2001) The longterm effect of tillage on soil displacement of hilly areas used for growing wheat in Greece. Soil Use Manage 17:113-120

Van Muysen W, Govers G (2002) Soil displacement and tillage erosion during secondary tillage operations: the case of rotary harrow and seeding equipment. Soil Tillage Res 65:185-191 